\title{
Peluang Penerapan fric Sebagai Instrumen Hukum Progresif \\ Untuk Melindungi Hak Masyarakat Adat Dalam Kegiatan \\ Usaha MinYaK DAN GAS BUMI
}

Nisa Istiqomah Nidasari ${ }^{1}$

\begin{abstract}
Abstrak
Pengadaan tanah untuk kegiatan industri minyak dan gas bumi merupakan kegiatan strategis yang diprioritaskan negara atas nama 'kepentingan umum'. Tidak jarang, pengadaan tersebut merampas hak tenurial masyarakat adat demi menyediakan lahan bagi perusahaan untuk melakukan eksplorasi dan eksploitasi. Padahal fungsi tanah bagi masyarakat adat tidak hanya sebagai tempat tinggal saja, tetapi juga sebagai tempat peribadatan, sumber mata pencaharian serta bagian dari budaya dan warisan leluhur yang harus dipertahankan dan dilestarikan. Hak masyarakat adat terhadap tanah ulayat juga dilindungi oleh berbagai instrumen hukum nasional dan internasional.

Salah satu prosedur yang dapat memberikan perlindungan terhadap hak-hak fundamental masyarakat adat adalah FPIC (Free, Prior and Informed Consent) atau PADIATAPA (Persetujuan Atas Dasar Informasi Awal Tanpa Paksaan). Secara khusus, tulisan ini bertujuan untuk menjawab pokok permasalahan sebagai berikut: Pertama, mengapa FPIC dapat menjadi instrumen hukum progresif untuk melindungi hak-hak masyarakat adat dalam kegiatan usaha migas? Kedua, bagaimana FPIC dapat meningkatkan kepastian hukum bagi investasi di sektor migas? Ketiga, bagaimana strategi untuk menerapkan FPIC dalam kebijakan pengadaan tanah untuk industri migas di Indonesia?
\end{abstract}

Kata kunci: Masyarakat Adat, Tanah Ulayat, Pengadaan Tanah untuk Kegiatan Industri Migas, PADIATAPA

${ }^{1}$ Peneliti pada Indonesian Center for Environmental Law (ICEL) 


\begin{abstract}
Land clearing for oil and gas industry is deemed as a strategic activity that is prioritized in the name of 'Public Interest'. In many cases, such land clearing confiscated the land tenure of indigenous peoples to give space for oil companies conducting exploration and exploitation. This is unacceptable for indigenous peoples because not only they often depend on their customary land for their livelihoods and residence, but also because it has strong cultural and often spiritual significance. The rights of indigenous peoples over their customary land is protected under national and international legal frameworks.

One of the procedure that shall gives a protection over the fundamental rights of Indigenous Peoples is FPIC (Free and Prior Informed Consent). In the business perspective, FPIC will increase the legal certainty for invesment as it provides the companies with social license to extract. Specifically, this paper will address the following questions: First, how FPIC could be a progressive legal instrument to protect Indigenous Peoples rights in the activity of oil and gas? Second, how FPIC could increase the legal certainty for investment in oil and gas industry? Third, what are the strategies to apply FPIC in the land clearing policy for oil and gas industry in Indonesia?
\end{abstract}

Key Words: Indigenous Peoples, Customary Land, Land Clearing in Oil and Gas Industry, FPIC

\title{
1. Pendahuluan
}

Bank Dunia, PBB dan berbagai lembaga internasional menyatakan bahwa terdapat sekitar 350 juta jumlah masyarakat adat di seluruh dunia dan $3 / 4$ nya berada di Asia. ${ }^{2}$ Di Indonesia sendiri, terdapat sekitar 50-70 juta masyarakat adat yang tersebar di berbagai pulau. ${ }^{3}$ Sayangnya, Indonesia selaku tuan rumah belum mampu menjamin hak-hak fundamental masyarakat adat sehingga masyarakat adat yang selama ini hidup dengan bersahaja dan memegang teguh kearifan lokal dari leluhur harus hidup dalam ketakutan. Bagaimana tidak? Masyarakat adat seringkali dipaksa untuk meninggalkan tanah yang telah mereka tinggali secara turun temurun serta diputus aksesnya terhadap hutan dan sumber mata pencaharian mereka demi menyediakan lahan bagi kegiatan industri ekstraktif. Sebagai contoh, pada tahun 2013 terdapat dua kasus yang

2 Rikka Sombolinggi, Jaringan akan Buat Peta Global Masyarakat Adat. http:/ / www.aman.or.id/2013/10/03/jaringan-akan-buat-peta-global-masyarakatadat/\#.VAuzhxYWS_w diakses pada 15 Oktober 2014.

3 AMAN. Indigenous World 2011 (Jakarta: AMAN, 2011), hal. 1. 
cukup mengkhawatirkan dimana masyarakat adat dipaksa untuk meninggalkan tanah ulayatnya: 1) konflik suku Sawai dan Tobelo Dalam melawan perusahaan nikel di Maluku Utara; dan 2) suku SambandateWalandawe melawan perusahaan tambang di Kabupaten Konawe, Sulawesi Tenggara. Pada kedua kasus tersebut, masyarakat adat tidak dilibatkan dalam konsultasi publik atas pemberian izin kepada perusahaan yang aktivitasnya berdampak langsung terhadap kelangsungan hidup mereka. Beberapa upaya untuk berdikusi tidak diindahkan oleh pemerintah dan perusahaan. Konflik sosial pun tidak terelakkan lagi bahkan di tahun 2012 masyarakat suku Sawai melawan dengan cara membakar alat-alat perusahaan dan berakhir di penjara. ${ }^{4}$ Dalam kasus seperti ini, tidak jarang ditemui polisi dan preman dikerahkan untuk meredam massa yang turun ke lapangan. AMAN mencatat sejak Oktober 2012-Maret 2013, telah terjadi kriminalisasi terhadap 224 orang masyarakat adat yang memprotes tindakan perusahaan dan aktif memperjuangkan hak-haknya atas tanah ulayat. $^{5}$

Data di atas sungguh mengecewakan mengingat Indonesia seharusnya memberikan jaminan hukum kepada masyarakat adat sebagaimana dimandatkan dalam Pasal 18B ayat (2) UUD 1945: "Negara mengakui dan menghormati kesatuan masyarakat hukum adat serta hak-hak tradisionalnya sepanjang masih hidup dan sesuai dengan perkembangan masyarakat dan prinsip NKRI...". Lebih jauh, hak-hak masyarakat adat merupakan hak asasi manusia yang dilindungi dalam UU No. 39 Tahun 1999 tentang Hak Asasi Manusia yang berbunyi:

(1) Dalam rangka penegakan hak asasi manusia, perbedaan dan kebutuhan dalam masyarakat hukum adat harus diperhatikan dan dilindungi oleh hukum, masyarakat, dan Pemerintah.

(2) Identitas budaya masyarakat hukum adat, termasuk hak atas tanah ulayat dilindungi, selaras dengan perkembangan zaman.

Di tingkat internasional, Indonesia juga telah menandatangani UN Declaration on the Rights of Indigenous Peoples yang berisi 46 Pasal perlindungan terhadap hak-hak masyarakat adat, dimana salah satu pasalnya berbunyi:

4 Kharina Triananda, Komnas: Hanya dari Kasus Tanah Banyak HAM yang bisa dilanggar: http://www.beritasatu.com/hukum/163078-komnas-hanya-dari-kasus-tanahbanyak-ham-yang-bisa-dilanggar.html , diakses pada 10 Oktober 2014.

5 Yance Arizona, Mengapa Undang-undang Masyarakat Adat dibutuhkan. http:/ / www.hukumpedia.com/masyarakat-adat/mengapa-undang-undang-masyarakatadat-dibutuhkan-hk522d348cacad7.html, diakses pada 10 Oktober 2014. 
Indigenous peoples shall not be forcibly removed from their lands or territories. No relocation shall take place without the free, prior and informed consent of the indigenous peoples concerned and after agreement on just and fair compensation and, where possible, with the option of return.

(Terjemahan bebas: Masyarakat adat tidak boleh diusir secara paksa dari tanah atau wilayah mereka tanpa FPIC. Tidak boleh ada relokasi yang dilakukan tanpa persetujuan masyarakat adat dan setelah adanya kesepakatan tentang kompensasi yang adil, serta apabila dimungkinkan, masyarakat adat memiliki hak untuk kembali).

Tindakan perusahaan dan pemerintah dalam mengklaim wilayah atau tanah yang sebenarnya milik masyarakat adat, menurut Sandra Moniaga (Komisioner Komnas HAM) telah melanggar beberapa Hak Asasi Manusia (HAM). Pelanggaran yang paling utama adalah terkait hak atas tanah. Kedua, hak atas pekerjaan karena pekerjaan masyarakat sebagai petani atau pemburu tentu akan terganggu. Ketiga adalah hak atas pangan, hal itu disebabkan sebagian hutan-hutan yang menyediakan makanan pokok mereka akan terancam, seperti hutan sagu atau area persawahan. Keempat, hak atas hidup, karena sebagian konflik agraria akan bernuansa kekerasan. Misalnya, saat perusahaan meminta polisi atau preman untuk menggusur masyarakat adat seringkali dengan menggunakan kekerasan dan menimbulkan korban jiwa. Terakhir, hak asasi manusia yang dilanggar adalah hak lingkungan hidup karena lingkungan sengaja dirusak untuk kepentingan proyek. ${ }^{6}$

Dari segi investasi, tingginya risiko konflik sosial sebagai bentuk protes masyarakat adat telah menyebabkan Indonesia tidak lagi merupakan tempat yang nyaman bagi investor. Berdasarkan Laporan First Peoples Worldwide tahun 2013 yang berjudul "Indigenous Rights Risk Report for the Extractive Industry", Indonesia termasuk negara dengan risiko tinggi untuk berinvestasi karena rawan akan terjadinya protests (demonstrasi), negative press (pencitraan negatif), work stoppages (penghentian proyek), shut-downs (penutupan), dan law suits (gugatan hukum) dari Indigenous Peoples yang dirugikan. Risiko-risiko tersebut apabila benar-benar terjadi tentu akan mengurangi keuntungan perusahaan

6 Kharina Triananda, Komnas: Hanya dari Kasus Tanah Banyak HAM yang Bisa Dilanggar. http://www.beritasatu.com/hukum/163078-komnas-hanya-dari-kasus-tanahbanyak-ham-yang-bisa-dilanggar.html , diakses pada 10 Oktober 2014. 
dan pada akhirnya menarik investor keluar dari indonesia. ${ }^{7}$ Hal ini tidak sejalan dengan kepentingan Indonesia untuk meningkatkan investasi asing di sektor migas. SKK Migas dan Kementerian ESDM mencatat bahwa cadangan minyak Indonesia akan habis dalam kurun waktu 12 tahun sedangkan cadangan gas bumi akan habis dalam 44 tahun. Karena itu perlu dilakukan eksplorasi untuk menemukan cadangan minyak dan gas baru dan pemerintah harus bekerja lebih keras lagi menarik investor untuk melakukan eksplorasi di daerah-daerah yang sulit dijangkau di bagian timur Indonesia. ${ }^{8}$

Melihat kondisi di atas, dibutuhkan suatu mekanisme yang dapat mempertemukan masyarakat adat dengan perusahaan dimana masyarakat adat bisa memperoleh informasi yang utuh tentang sebuah proyek yang akan dilangsungkan di tanah ulayat dan yang akan berdampak pada kehidupan mereka. Tidak hanya itu, masyarakat adat juga diberikan hak untuk menyatakan setuju atau tidak setuju terhadap aktivitas/proyek tersebut. Mekanisme ini lebih dikenal dengan istilah Free, Prior, and Informed Consent (FPIC). ${ }^{9}$

Untuk mengelaborasi lebih lanjut tentang FPIC dan kemungkinan penerapannya di Indonesia, tulisan ini bermaksud untuk membahas tiga pokok permasalahan: Pertama, bagaimana FPIC dapat menjadi instrumen hukum progresif untuk melindungi hak-hak masyarakat adat dalam kegiatan usaha migas? Kedua, bagaimana FPIC dapat meningkatkan kepastian hukum bagi investasi di sektor migas? Ketiga, bagaimana strategi untuk menerapkan FPIC dalam kebijakan pengadaan tanah untuk industri migas di Indonesia?

Tulisan ini akan didahului dengan sebuah paparan tentang apa yang dimaksud dengan masyarakat adat dihubungkan dengan istilah populer internasional: 'Indigenous Peoples', kemudian akan dilanjutkan dengan pembahasan apa itu FPIC serta unsur, prinsip dan prosedur umum dari FPIC. Selanjutnyas tulisan ini akan masuk pada tigas pokok permasalahan di atas lalu ditutup dengan kesimpulan.

\footnotetext{
7 First People Worldwide. Indigenous Rights Risk Report for the Extractive Industry, (Uniter States: First People Worldwide, 2013) Hal. 12.

8 Indonesia SOS Energi Investasi Asing. http://indonesiainvesttoday.com/2013/11/indonesia-sos-energi-investasi-asing-di.html, diakses pada 9 Oktober 2014.

9 Dewan Kehutanan Nasional dan UN-REDD Programme Indonesia. Rekomendasi Kebijakan: Instrumen Free, Prior, Informed Concent (FPIC) Bagi Masyarakat Adat dan atau Masyarakat Lokal yang Akan Terkena Dampak dalam Aktivitas Redd+ di Indonesia, (Jakarta: DKN, 2011), hal.3
} 


\section{Istilah dan Definisi Masyarakat Adat di Indonesia}

Di Indonesia, istilah dan definisi masyarakat adat sangat beragam. Dari sisi istilah misalnya, ada peraturan yang menggunakan istilah komunitas adat terpencil, masyarakat adat, masyarakat hukum adat, kesatuan masyarakat hukum adat, maupun istilah masyarakat tradisional. ${ }^{10}$ Sedangkan dari sisi definisi, berikut beberapa definisi yang penting dikemukakan dalam tulisan ini:

\begin{tabular}{|c|c|}
\hline $\begin{array}{c}\text { Peraturan dan istilah yang } \\
\text { digunakan }\end{array}$ & Definisi dan Kriteria \\
\hline $\begin{array}{l}\text { Pasal 18B ayat (2) UUD } 1945 \\
\text { Kesatuan Masyarakat Hukum } \\
\text { Adat }\end{array}$ & $\begin{array}{l}\text { Kesatuan masyarakat hukum adat diakui: } \\
\text { 1. sepanjang masih hidup } \\
\text { 2. sesuai dengan perkembangan masyarakat } \\
\text { 3. } \text { sesuai dengan prinsip Negara Kesatuan } \\
\text { Republik Indonesia }\end{array}$ \\
\hline $\begin{array}{l}\text { UU No. } 41 \text { Tahun } 1999 \\
\text { tentang Kehutanan } \\
\text { Masyarakat Hukum Adat }\end{array}$ & $\begin{array}{l}\text { Masyarakat hukum adat memenuhi kriteria } \\
\text { 1. masyarakatnya masih dalam bentuk } \\
\text { paguyuban (rechsgemeenschap); } \\
\text { 2. ada kelembagaan dalam bentuk perangkat } \\
\text { penguasa adatnya; } \\
\text { 3. ada wilayah hukum adat yang jelas; } \\
\text { 4. ada pranata hukum, khususnya peradilan } \\
\text { adat, yang masih ditaati; dan } \\
\text { 5. masih mengadakan pemungutan hasil hutan } \\
\text { di wilayah hutan sekitarnya untuk } \\
\text { pemenuhan kebutuhan hidup sehari-hari. }\end{array}$ \\
\hline $\begin{array}{l}\text { UU No. } 7 \text { tahun } 2004 \text { tentang } \\
\text { Sumber Daya Air } \\
\text { Masyarakat Hukum Adat }\end{array}$ & $\begin{array}{l}\text { Masyarakat hukum adat adalah sekelompok } \\
\text { orang yang terikat oleh tatanan hukum adatnya } \\
\text { sebagai warga bersama suatu persekutuan } \\
\text { hukum adat yang didasarkan atas kesamaan }\end{array}$ \\
\hline
\end{tabular}

10 Yance Arizona, New York 2014: Mendefinisikan Indigenous Peoples di Indonesia. http://yancearizona.net/tag/masyarakat-hukum-adat/, diakses pada 19 Desember 2014. 


\begin{tabular}{|c|c|}
\hline $\begin{array}{c}\text { Peraturan dan istilah yang } \\
\text { digunakan }\end{array}$ & Definisi dan Kriteria \\
\hline & tempat tinggal atau atas dasar keturunan. \\
\hline $\begin{array}{l}\text { UU No. } 18 \text { Tahun } 2004 \\
\text { tentang Perkebunan } \\
\text { Masyarakat Hukum Adat }\end{array}$ & $\begin{array}{l}\text { Masyarakat hukum adat memenuhi kriteria: } \\
\text { 1. masyarakat masih dalam bentuk paguyuban } \\
\text { (rechtsgememschaft); } \\
\text { 2. ada kelembagaan dalam bentuk perangkat } \\
\text { penguasa adat; } \\
\text { 3. ada wilayah hukum adat yang jelas; } \\
\text { 4. ada pranata dan perangkat hukum, } \\
\text { khususnya peradilan adat yang masih } \\
\text { ditaati; dan } \\
\text { 5. ada pengukuhan dengan peraturan daerah. }\end{array}$ \\
\hline $\begin{array}{l}\text { UU No. } 32 \text { Tahun } 2004 \\
\text { tentang Pemerintahan Daerah } \\
\text { Kesatuan } \quad \text { Masyarakat Hukum } \\
\text { Adat }\end{array}$ & $\begin{array}{l}\text { Kesatuan masyarakat hukum adat memenuhi } \\
\text { unsur: } \\
\text { 1. sepanjang masih hidup } \\
\text { 2. sesuai dengan perkembangan masyarakat } \\
\text { 3. sesuai dengan prinsip Negara Kesatuan } \\
\text { Republik Indonesia }\end{array}$ \\
\hline $\begin{array}{|lr|}\text { UU } 32 \text { Tahun } 2009 \text { tentang } \\
\text { Perlindungan } & \text { dan } \\
\text { Pengelolaan } & \text { Lingkungan } \\
\text { Hidup } & \\
\text { Masyarakat Hukum Adat }\end{array}$ & $\begin{array}{l}\text { Masyarakat hukum adat adalah kelompok } \\
\text { masyarakat yang secara turun temurun } \\
\text { bermukim di wilayah geografis tertentu karena } \\
\text { adanya ikatan pada asal usul leluhur, adanya } \\
\text { hubungan yang kuat dengan lingkungan hidup, } \\
\text { serta adanya sistem nilai yang menentukan } \\
\text { pranata ekonomi, politik, sosial, dan hukum. }\end{array}$ \\
\hline 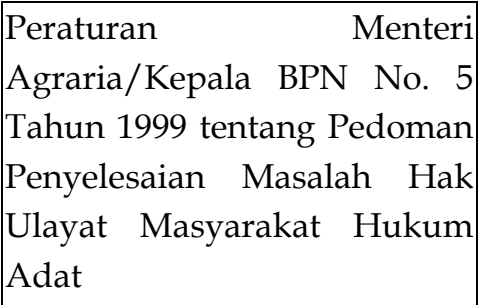 & $\begin{array}{l}\text { Masyarakat hukum adat adalah sekelompok } \\
\text { orang yang terikat oleh tatanan hukum adatnya } \\
\text { sebagai warga bersama suatu persekutuan } \\
\text { hukum karena kesamaan tempat tinggal } \\
\text { ataupun atas dasar keturunan. }\end{array}$ \\
\hline
\end{tabular}




\begin{tabular}{|c|c|}
\hline $\begin{array}{c}\text { Peraturan dan istilah yang } \\
\text { digunakan }\end{array}$ & Definisi dan Kriteria \\
\hline Masyarakat Hukum Adat & \\
\hline $\begin{array}{l}\text { Keputusan Presiden No. } 111 \\
\text { Tahun } 1999 \text { tentang } \\
\text { Pembinaan Kesejahteraan } \\
\text { Sosial Komunitas Adat } \\
\text { Terpencil. } \\
\text { Komunitas Adat Terpencil }\end{array}$ & $\begin{array}{l}\text { Komunitas adat terpencil atau yang selama ini } \\
\text { lebih dikenal dengan sebutan masyarakat } \\
\text { terasing adalah kelompok sosial budaya yang } \\
\text { bersifat lokal dan terpencar serta kurang atau } \\
\text { belum terlihat dalam jaringan dan pelayanan } \\
\text { baik sosial, ekonomi, maupun politik. } \\
\text { Ciri-ciri Komunitas Adat Terpencil antara lain: } \\
\text { 1. berbentuk komunitas kecil, tertutup, dan } \\
\text { homogen; } \\
\text { 2. pranata sosial bertumpu pada hubungan } \\
\text { kekerabatan; } \\
\text { 3. pada umumnya terpencil secara geografi dan } \\
\text { relatif sulit dijangkau; } \\
\text { 4. pada umumnya masih hidup dengan sistem } \\
\text { ekonomi subsistems; } \\
\text { 5. peralatan dan teknologinya sederhana; } \\
\text { 6. ketergantungan pada lingkungan hidup dan } \\
\text { sumber daya alam setempat relatif tinggi; } \\
\text { 7. terbatasnya akses pelayanan sosial, ekonomi, } \\
\text { dan politik. }\end{array}$ \\
\hline $\begin{array}{l}\text { Definisi kerja Aliansi } \\
\text { Masyarakat Adat Nusantara } \\
\text { (AMAN) } \\
\text { Masyarakat Adat }\end{array}$ & $\begin{array}{l}\text { Masyarakat adat adalah kelompok masyarakat } \\
\text { yang secara turun temurun bermukim di } \\
\text { wilayah geografis tertentu di Negara Indonesia } \\
\text { karena adanya ikatan pada asal usul leluhur, } \\
\text { adanya hubungan yang kuat dengan tanah, } \\
\text { wilayah dan sumber daya alam di wilayah } \\
\text { adatnya, serta adanya sistem nilai yang } \\
\text { menentukan pranata ekonomi, politik, sosial } \\
\text { dan hukum yang berbeda, baik sebagian } \\
\text { maupun seluruhnya dari masyarakat pada } \\
\text { umumnya. }\end{array}$ \\
\hline
\end{tabular}


Terminologi masyarakat adat dalam tingkat internasional sering dipadankan dengan istilah indigenous people. Namun, hingga saat ini belum ada satu definisi hukum atas Indigenous Peoples yang diakui secara internasional. Hal ini dikarenakan karakteristik Indigenous Peoples yang diperkirakan berjumlah 370 juta yang tersebar di 70 negara di dunia ${ }^{11}$ tersebut sangat beragam. Namun demikian, PBB telah menggariskan karakteristik umum dari Indigenous Peoples yang bertujuan untuk tetap dapat membedakannya dengan kelompok masyarakat minoritas lain ${ }^{12}$. Karakteristik-karakteristik tersebut adalah sebagai berikut:

1. Keberlanjutan sejarah dengan masyarakat asli (pre-colonial and/or presettler societies);

2. Kekhasan (distinctiveness) sistem sosial, ekonomi dan politik;

3. Kekhasan (distinctiveness) dari segi bahasa, budaya, dan kepercayaan;

4. Hubungan yang kuat dengan tanah dan sumber daya alam yang ada di sekitarnya;

5. Membentuk kelompok yang tidak dominan (non-dominant group) di masyarakat;

6. Keinginan untuk menjaga, mempertahankan dan meneruskan tanah adat, sistem adat beserta tradisinya kepada generasi berikutnya. ${ }^{13}$

Berdasarkan karakteristik Indigenous Peoples di atas, kita dapat menemukan bahwa karakteristik tersebut pada umumnya sama dengan karakteristik masyarakat adat di Indonesia. Namun demikian, terdapat kalangan yang menganggap bahwa masyarakat adat tidak bisa disamakan dengan Indigenous Peoples karena konsep Indigenous Peoples pada awalnya berkembang dari pengalaman kolonialisme, dimana mereka mengalami marginalisasi atas invasi yang dilakukan oleh penjajah. ${ }^{14}$ Penguasa kolonial ini kemudian masih menjadi kekuatan dominan pasca negara-negara terbentuk sebagaimana terjadi di benua Amerika, Rusia, Antartika dan negara-negara di Pasifik. ${ }^{15}$ Hal ini berbeda dengan gerakan masyarakat adat di Indonesia yang berkembang pada awal

11 United Nations Permanent Forum on Indigenous Issues. Who Are Indigenous People? 2014. hal. 1

12 The Global Oil and Gas Industry Association for Environmental and Social Issues (IPIECA), Indigenous Peoples and the Oil and Gas Industry, (UK: IPIECA, 2012), hal. 5.

13United Nations Permanent Forum on Indigenous Issues. Who Are..., hal. 1.

14 Yance Arizona, New York..., diakses pada 19 Desember 2014.

15 The State of the World's Indigenous Peoples, State of the World's Indigenous Peoples. (United Nation, New York: 2009), hal. 6. 
dekade 1990-an untuk merespons persoalan-persoalan yang ditimbulkan dari dampak program pembangunan yang dicanangkan oleh Pemerintah Orde Baru. Permasalahan itu baik dalam bentuk diskriminasi, perampasan tanah, pengusiran, dan kekerasan lainnya. ${ }^{16}$ Karenanya, definisi masyarakat adat dianggap lebih dekat dengan istilah masyarakat suku/Tribal Peoples ${ }^{17}$ dibanding Indigenous Peoples. Perbedaan ini sebenarnya telah coba dijembatani melalui sebuah kajian yang dilakukan oleh United Nation Permanent Forum on Indigenous Issue pada tahun 2004 yang berjudul The Concept of Indigenous Peoples (PFII/2004/WS.1/3) yang menyimpulkan:

The two terms "indigenous peoples" and "tribal peoples" are used by the ILO because there are tribal peoples who are not "indigenous" in the literal sense in the countries in which they live, but who nevertheless live in a similar situation - an example would be Afro-descended tribal peoples in Central America; or tribal peoples in Africa such as the San or Maasai who may not have lived in the region they inhabit longer than other population groups. Nevertheless, many of these peoples refer to themselves as "indigenous" in order to fall under discussions taking place at the United Nations. For practical purposes the terms "indigenous" and "tribal" are used as synonyms in the UN system when the peoples concerned identify themselves under the indigenous agenda.

(Terjemahan bebas : Dua istilah "indigenous peoples" dan "tribal peoples" digunakan oleh ILO karena terdapat tribal peoples yang tidak "indigenous" dalam pengertian harfiah di negara tempat mereka tinggal, tetapi bagaimanapun juga hidup dalam situasi yang hampir sama - contohnya tribal peoples keturunan Afrika yang tinggal di Amerika Tengah; atau tribal peoples di Africa seperti San atau Maasai yang mungkin tidak tinggal di daerah yang mereka tempati lebih lama dari kelompok masyarakat lainnya. Namun demikian, banyak dari kelompok masyarakat ini yang menyebut dirinya "indigenous" agar dapat termasuk dalam diskusi yang sedang berlangsung di PBB. Untuk kepentingan praktis, istilah "indigenous" dan "tribal" akan digunakan sebagai sinonim dalam sistem PBB sepanjang kelompok masyarakat yang bersangkutan mengidenfikasikan dirinya di bawah agenda indigenous).

16http://yancearizona.net. diakses pada 1 Desember 2014.

17 Berdasarkan Konvensi ILO No. 169, definisi "Tribal peoples" adalah: peoples in independent countries whose social, cultural and economic conditions distinguish them from other sections of the national community, and whose status is regulated wholly or partially by their own customs or traditions or by special laws or regulations." 
Atas dasar tersebut, dalam tulisan ini penulis akan menggunakan istilah Indigenous Peoples sebagai sinonim dari istilah Masyarakat Adat.

\section{Free Prior Informed Consent (FPIC)}

\subsection{Definisi FPIC}

FPIC (Free and Prior Informed Consent) adalah sebuah mekanisme atau suatu proses yang memungkinkan masyarakat menyatakan 'setuju' atau 'tidak setuju' terhadap sebuah aktivitas, proyek, atau kebijakan yang akan dilaksanakan di ruang kehidupan masyarakat dan berpotensi berdampak kepada tanah, kawasan, sumber daya dan perikehidupan masyarakat. ${ }^{18}$ Menilik sejarah, FPIC pada awalnya digunakan untuk melindungi kepentingan pasien di rumah sakit yang semestinya mengetahui setiap proses dan jenis pengobatan yang akan dilaluinya sebelum tindakan medis tersebut dijalankan. Salah satu kodifikasi pertama FPIC di dunia adalah Kode Nuremberg tahun 1947 yang berhubungan dengan syarat melakukan riset dan eksperimen medis terhadap manusia. ${ }^{19}$ Dari sinilah konsep FPIC berkembang dari semula konsep perlindungan terhadap hak pasien menjadi konsep perlindungan terhadap hakhak Indigenous Peoples dalam berbagai kaidah hukum internasional. ${ }^{20}$

Bagi masyarakat adat atau lokal di Indonesia, konsep FPIC bukanlah konsep baru yang diintrodusir oleh pihak asing. Konsep ini sebenarnya telah mengakar pada tradisi dan kebiasaan masyarakat adat atau lokal dalam bentuk musyarawarah untuk melakukan pemanfaatan aset dan potensi yang dimiliki dengan pihak luar. ${ }^{21}$

\subsection{Unsur-unsur dalam FPIC}

FPIC memiliki empat unsur/elemen yaitu Free, Prior, Informed dan Consent yang mengandung pengertian sebagai berikut:22

${ }^{18}$ DKN, UN REDD Programme Indonesia. Rekomendasi Kebijakan... hal. 13

19 Robert Goodland. FPIC and the World Bank Group. (Sustainable Development Law and Policy: 2004), hal.67.

${ }^{20}$ Bernadinus Steny. FPIC dalam Pergulatan Hukum Lokal. (HUMA, Jakarta: 2005). Hal. 11.

${ }^{21}$ Panduan. Tim Penulis Pokja IV. Panduan Pelaksanaan..., hal. 5.

22 DKN, UN REDD Programme Indonesia. Rekomendasi Kebijakan..., hal. 6-7. 
(1) Free bermakna bahwa masyarakat adat memberikan persetujuan atau memutuskan untuk tidak menyetujui sebuah rencana aktivitas, proyek atau kebijakan tanpa ada paksaan dari pihak manapun. Masyarakat adat bebas dari tekanan, ancaman untuk berpendapat; masyarakat tidak dalam tekanan waktu dan tempat untuk bernegosiasi; dan masyarakat adat juga bebas memilih siapa saja yang harus mewakili mereka.

(2) Prior bermakna bahwa perolehan keputusan apakah setuju/tidak itu dilakukan sebelum kebijakan atau kegiatan itu dilakukan. Kendati demikian, dalam keadaan memaksa dapat juga persetujuan masyarakat diperoleh saat kegiatan sedang berlangsung.

(3) Informed bermakna bahwa sebelum proses pemberian keputusan, masyarakat harus benar-benar mendapat informasi yang utuh dalam bahasa dan bentuk yang mudah dimengerti oleh masyarakat. Informasi seharusnya disampaikan oleh personel yang memahami konteks budaya setempat, dapat berbicara dengan bahasa setempat dan memasukan aspek pengembangan kapasitas masyarakat lokal. Informasi seharusnya lengkap dan objektif termasuk potensi dampak sosial, politik, budaya dan lingkungan hidup dan memberikan informasi kepada masyarakat baik mengenai keuntungan maupun kerugian potensial yang akan diterima oleh masyarakat sebelum persetujuan diberikan.

(4) Consent bermakna bahwa suatu keputusan atau kesepakatan yang dicapai melalui sebuah proses terbuka dan bertahap yang menghargai hukum adat atau lokal secara kolektif dengan segala otoritas yang dianut oleh mereka sendiri.

\subsection{Prinsip-prinsip FPIC}

Dalam menerapkan FPIC untuk masyarakat adat, pengembang proyek harus memperhatikan prinsip-prinsip pengakuan dan penghormatan hak masyarakat adat yang diatur di dalam Deklarasi PBB tentang hak Indigenous Peoples sebagai bagian dari instrumen hak asasi manusia internasional, yaitu sebagai berikut:

- Pasal 3: Indigenous peoples have the right to self-determination. By virtue of that right they freely determine their political status and freely pursue their economic, social and cultural development.

Terjemahan bebas: Masyarakat adat mempunyai hak untuk menentukan nasib sendiri. Berdasarkan hak tersebut, mereka dapat 
secara bebas menentukan status politiknya serta mengejar pembangunan di bidang ekonomi, sosial dan budaya.

- Pasal 10: Indigenous peoples cannot be forcibly removed from their lands and territories and relocated without FPIC

Terjemahan bebas:Masyarakat adat tidak boleh diusir secara paksa dari tanah atau wilayah mereka tanpa FPIC.

- Pasal 11: Redress shall be given to indigenous peoples whose cultural, intellectual, religious and spiritual property are taken without their FPIC;

Terjemahan bebas: ganti rugi harus diberikan kepada masyarakat adat yang kebudayaannya, properti intelektualnya, agama dan spiritualitasnya diambil tanpa FPIC;

- Pasal 19: FPIC must be obtained before adopting or implementing legislative/administrative measures affecting indigenous peoples;

Terjemahan bebas: FPIC harus diperoleh sebelum mengadopsi atau mengimplementasikan tindakan legislatif/administratif yang akan berdampak pada masyarakat adat.

- Pasal 28: Indigenous peoples have the right to redress for lands, territories, resources, which were confiscated, taken, occupied, used or damaged without their FPIC.

Terjemahan bebas:Masyarakat adat mempunyai hak atas ganti rugi atas tanah, wilayah, sumber daya alam yang disita, diambil, diduduki, digunakan dan dirusak tanpa FPIC.

- Pasal 32: FPIC should be obtained prior to approval of any project affecting their lands, territories and resources, particularly exploitation of mineral, water and other resources.

Terjemahan bebas: FPIC wajib diperoleh sebelum adanya persetujuan terhadap proyek apapun yang dapat berdampak pada tanah, wilayah dan sumber daya alam milik masyarakat adat, khususnya proyek yang berkaitan dengan eksploitasi mineral, air dan sumber daya alam lainnya.

\subsection{Prosedur Umum FPIC}

Sebagaimana diungkapkan oleh Anderson dalam bukunya Free, Prior, and Informed Consent: Principles and Approaches for Policy and Project (2011), prosedur FPIC akan sangat bergantung pada tradisi yang berlaku di kalangan 
masyarakat adat sehingga tidak mungkin untuk menciptakan suatu prosedur FPIC yang berlaku untuk semua dan diakui secara universal. Namun demikian tetap dimungkinkan untuk mengidentifikasi elemen-elemen kunci dalam proses FPIC dengan catatan bahwa hal ini harus tetap disesuaikan dengan proses yang diterima secara adat. ${ }^{23}$ Berikut ini penulis uraikan prosedur FPIC secara umum:

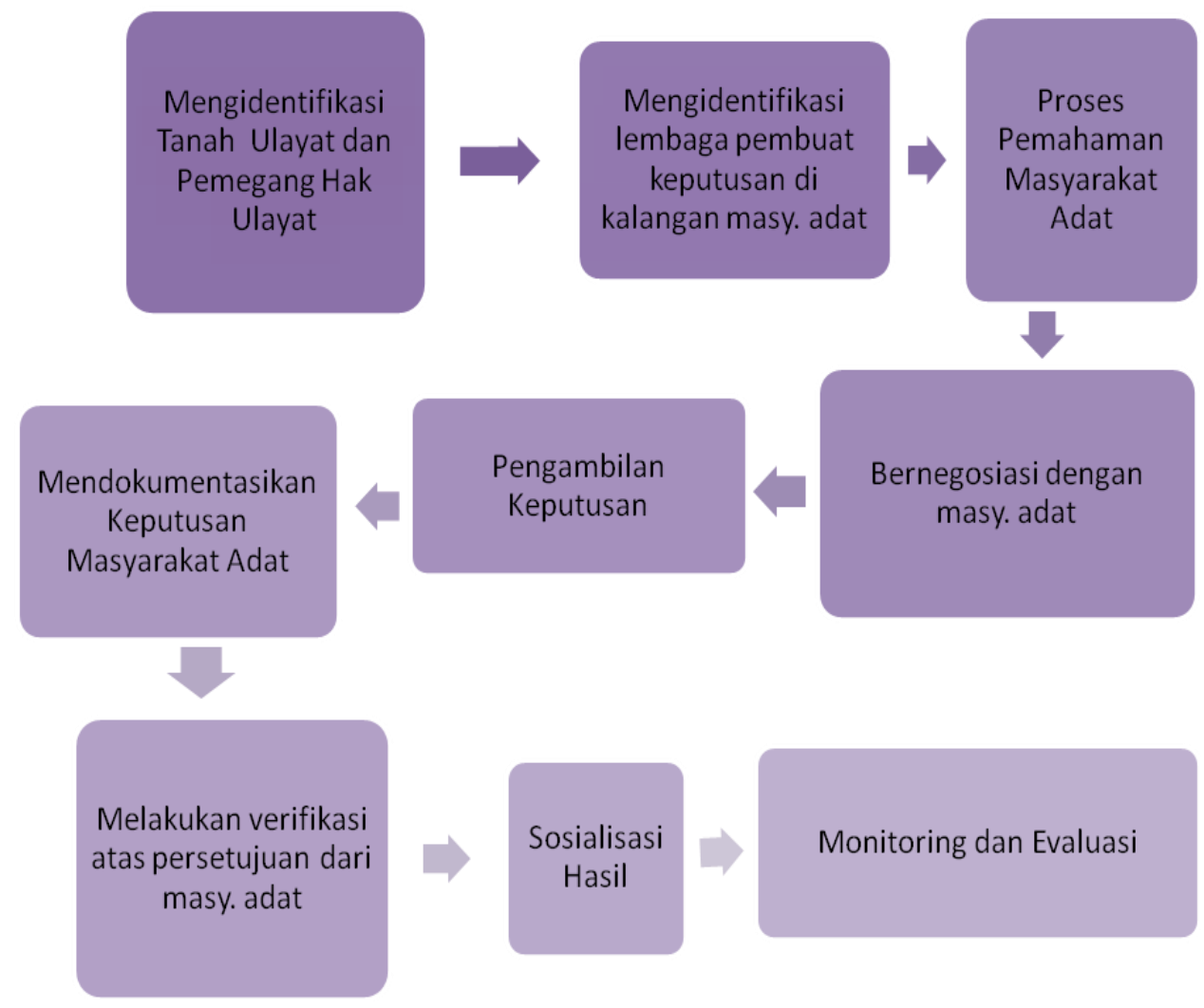

Bagan I: Prosedur FPIC

\section{A. Mengidentifikasi Tanah Ulayat dan Pemegang hak Ulayat}

Langkah ini merupakan fondasi penting dalam proses FPIC karena dengan mengidentifikasi tanah ulayat dan siapa pemegang hak atas tanah ulayat, kita dapat mengetahui siapa yang perlu dimintai persetujuannya atas Kegiatan Usaha Migas yang hendak dilaksanakan.

23 Patrick Anderson, Free, Prior, and Informed Consent: Principles and Approaches for Policy and Project Development,(Bangkok, GIZ \& RECOFTC, 2011), hal. 3. 
Definisi Tanah Ulayat diatur di dalam Peraturan Menteri Agraria/Kepala BPN No. 5 Tahun 1999 tentang Pedoman Penyelesaian Masalah Hak Ulayat Masyarakat Hukum Pasal 1 angka 2 yang berbunyi: “Tanah Ulayat adalah bidang tanah yang diatasnya terdapat hak ulayat dari suatu masyarakat hukum adat tertentu." Adapun yang dimaksud dengan Hak Ulayat diatur dalam Pasal 1 angka 1 sebagai berikut:

"Hak Ulayat dan yang serupa itu dari masyarakat hukum adat, (untuk selanjutnya disebut hak ulayat), adalah kewenangan yang menurut hukum adat dipunyai oleh masyarakat hukum adat tertentu atas wilayah tertentu yang merupakan lingkungan para warganya untuk mengambil manfaat dari sumber daya alam, termasuk tanah, dalam wilayah tersebut, bagi kelangsungan hidup dan kehidupannya, yang timbul dari hubungan secara lahiriah, batiniah turun temurun dan tidak terputus antara masyarakat hukum adat tersebut dengan wilayah yang bersangkutan."

Ketentuan tentang pemegang hak ulayat di suatu wilayah dapat ditelusuri dari Peraturan Daerah (Perda) yang mengatur tentang kelembagaan adat, sebagai contoh pada tahun 2008 Pemerintah Provinsi Sumatera Barat membuat Perda No. 6/2008 tentang Tanah Ulayat dan Pemanfaatannya. Di dalam Perda tersebut, diatur jenis-jenis tanah ulayat dan siapa penguasa serta pemilik tanah ulayat tersebut, sebagai berikut:

\begin{tabular}{|c|c|l|}
\hline No. & Jenis Tanah Ulayat & \multicolumn{1}{|c|}{$\begin{array}{c}\text { Penguasa dan Pemilik } \\
\text { Tanah Ulayat }\end{array}$} \\
\hline 1. & $\begin{array}{l}\text { Tanah Ulayat } \\
\text { Nagari }\end{array}$ & Ninik mamak KAN \\
\hline 2. & Tanah Ulayat Suku & Penghulu-penghulu suku \\
\hline 3. & Tanah Ulayat Rajo & $\begin{array}{l}\text { Lelaki Tertua Pewaris Rajo } \\
\text { mewakili anggota kaum } \\
\text { dalam garis keturunan ibu }\end{array}$ \\
\hline
\end{tabular}

Di Kalimantan Tengah juga ditemukan Perda serupa yaitu Perda No. 1 Tahun 2010 tentang Perubahan Atas Peraturan Daerah Provinsi kalimantan Tengah No. 16 Tahun 2008 tentang Kelembagaan Adat Dayak 
di Kalimantan Tengah. Di dalam Perda tersebut, Damang Kepala Adat yang bertugas mengelola hak-hak adat atau harta kekayaan Kedamangan untuk mempertahankan dan meningkatkan kemajuan dan taraf hidup masyarakat hidup masyarakat ke arah yang lebih baik.

Meskipun terdapat beberapa pemerintah daerah yang menerbitkan Perda semacam ini, masih banyak tanah ulayat yang belum diinventarisir dengan baik dan diakui secara formal dalam instrumen peraturan perundang-undangan seperti Perda dan banyak pemegang hak ulayat yang belum mengurus Sertifikat Tanah Ulayat ke BPN, meskipun secara de facto bertindak sebagai penguasa dan pemilik atas tanah ulayat tersebut. Dalam hal demikian, pemerintah dan/atau pengusaha dapat memanfaatkan Peta Indikatif Wilayah Adat Indonesia yang diinisiasi oleh Jaringan Kerja Pemetaan Partisipatif (JKPP) bersama dengan Aliansi Masyarakat Adat Nusantara (AMAN) untuk menelusuri keberadaan tanah ulayat dan masyarakat adat yang menempati daerah yang dituju. Peta Indikatif Wilayah Adat ini sudah diintegrasikan dalam One Map Indonesia yang dibuat oleh UKP4. ${ }^{24}$ Apabila wilayah yang dituju belum ada di peta ini, pemerintah dan/atau pengusaha dapat melakukan pemetaan partisipatif dengan melibatkan berbagai kelompok masyarakat lokal dan masyarakat adat yang menempati wilayah tersebut serta yang menempati wilayah lain yang berbatasan langsung untuk memvalidasi batas-batas wilayah. ${ }^{25}$

\section{B. Mengidentifikasi lembaga pembuat keputusan di kalangan Masyarakat Adat}

Dalam kerangka hukum internasional, masyarakat adat berhak untuk diwakili oleh suatu lembaga yang mereka pilih sendiri yang mungkin berbeda dengan lembaga formil yang dibentuk pemerintah. ${ }^{26}$ Sebagai contoh, masyarakat adat di Kab. Kampar, Riau, mempunyai lembaga bernama Kerapatan Adat yang merupakan satu-satunya lembaga permusyawaratan tertinggi adat yang mengatur tentang penggunaan dan atau pemanfaatan serta pemindahan kepemilikan Tanah Ulayat. Berdasarkan hukum adat setempat, Kerapatan Adat

24 IGG Maha Adi, Masyarakat Adat Lengkapi One Map Indonesia. http://ekuatorial.com/en/climate-change/masyarakat-adat-lengkapi-one-map-indonesia diakses pada 23 Oktober 2014

${ }_{25}$ World Wildlife Fund. Free, Prior, Informed Consent and Redd+: Guidelines and Resources. (Indonesia: WWF, 2011) hal. 4.

${ }^{26}$ Ibid. 
adalah suatu wadah atau organisasi persidangan para Ninik Mamak ${ }^{27}$ atau warga yang dituahkan dan ditaudalani secara turun temurun dalam suatu masyarakat adat. Ketentuan Kerapatan Adat merupakan suatu ketentuan hukum yang mengikat bagi setiap warga masyarakat. ${ }^{28}$

Dalam meminta persetujuan, pemrakarsa proyek harus menghormati keberadaan dari lembaga adat yang mempunyai kewenangan untuk membuat keputusan tentang pemanfaatan tanah ulayat berdasarkan hukum adat yang berlaku.

\section{Proses Pemahaman Masyarakat Adat tentang Proyek yang diusung}

Kegiatan ini dimaksudkan untuk memberikan pemahaman masyarakat terhadap proyek yang akan dilangsungkan di tanah ulayat. Proses ini dapat dilakukan melalui FGD, penyebaran leaflet, brosur, cerita bergambar (cergam), film, animasi, dan media pendukung lainnya yang relevan serta bertujuan agar informasi yang diberikan konsisten, seragam, lengkap dan jelas. ${ }^{29}$

Segala informasi tentang kegiatan usaha Migas yang akan dilaksanakan di Tanah Ulayat beserta dampak sosial dan lingkungannya harus disampaikan dengan sebenar-benarnya kepada masyarakat adat dengan cara:

- Terbuka dan transparan;

- Menggunakan bahasa daerah/bahasa yang dimengerti oleh masyarakat adat;

- Disampaikan dengan cara yang dapat diterima secara adat. ${ }^{30}$

Free, Prior, Informed Consent and REDD+: Guidelines and Resources memberikan panduan tentang informasi apa saja yang perlu disampaikan kepada masyarakat adat, yaitu:

\footnotetext{
27 Ninik, Mamak adalah orang yang dinobatkan atau diangkat oleh persukuannya dan atau kaumnya untuk memimpin persukuan atau kaumnya sendiri, yang telah dikukuhkan atau dinobatkan secara sah oleh persekutusannya sesuai dengan hukum adat setempat

28 Perda Pemkab Kampar No. 12 Tahun 1999 tentang Hak Tanah Ulayat.

29 Tim Penulis Pokja IV. Panduan Pelaksanaan... Hal 35.

30 World Wildlife Fund. Free, Prio... Hal. 5.
} 
- Dampak positif dan dampak negatif dari kegiatan usaha migas. Informasi ini harus disampaikan secara seimbang tanpa ada penekanan di dampak positifnya saja;

- Asesmen tentang biaya dan manfaat (cost and benefit analysis) dari kegiatan yang dimaksud;

- Alternatif kegiatan lain yang dapat dilangsungkan di atas tanah ulayat, beserta hasilnya (outcome);

- Informasi tentang hak-hak masyarakat adat;

- Informasi tentang akibat hukum dari proyek yang diusulkan seperti akibatnya terhadap status tanah, hak masyarakat adat terhadap sumber daya alam dan lain-lain. ${ }^{31}$

Mengingat masih lemahnya kapasitas masyarakat adat untuk memahami dampak dari proyek khususnya sehubungan dengan kegiatan usaha migas, pemerintah harus berperan dalam memberikan bantuan teknis agar masyarakat adat dapat benar-benar memahami informasi yang disampaikan. Misalnya dengan memberikan edukasi, menerjemahkan istilah-istilah teknis ke bahasa yang mudah dimengerti, dan tindakan afirmatif lainnya. ${ }^{32}$

\section{Bernegosiasi dengan Masyarakat Adat}

Negosisasi dilakukan dengan cara komunikasi dua arah antara masyarakat adat dengan pemrakarsa proyek (Pemerintah, BUMN atau perusahaan swasta) tentang proposal kegiatan usaha Migas. Beberapa isu-isu kunci dapat dibicarakan dalam negosiasi ini seperti perubahan pemanfaatan lahan, keterlibatan masyarakat adat, kemungkinan relokasi, ganti rugi dan kompensasi yang akan diterima oleh masyarakat adat, mekanisme penyelesaian sengketa dan lain sebagainya. Negosiasi biasanya membutuhkan waktu yang tidak sebentar untuk memberikan kesempatan bagi pemimpin masyarakat adat dan anggotanya mendiskusikan proposal proyek di internal mereka. ${ }^{33}$

${ }^{31}$ Ibid.

32 tindakan afirmatif adalah kebijakan yang diambil yang bertujuan agar kelompok/golongan tertentu (gender ataupun profesi) memperoleh peluang yang setara dengan kelompok/golongan lain dalam bidang yang sama. Sumber: Hukum Online, link: http://www.hukumonline.com/klinik/detail/cl6904/affirmative-action diakses pada 20 Desember 2014.

33Ibid. hal. 6. 


\section{E. Pengambilan Keputusan Masyarakat Adat}

Pengambilan keputusan oleh masyarakat adat dilakukan berdasarkan tradisi dan hukum adat yang berlaku sesuai dengan poin nomor satu dan dua di atas. Tahap ini akan menjawab komponen consent dalam FPIC, dimana semua perwakilan masyarakat adat yang terpilih akan mengambil keputusan terkait peran, tanggung jawab, manfaat yang diterima dan dampak yang akan ditimbulkan serta sejumlah opsi lainnya. ${ }^{34}$

\section{F. Mendokumentasikan Keputusan Masyarakat Adat}

Keputusan serta kesepakatan yang tercipta antara pengembang proyek dengan masyarakat adat perlu didokumentasikan dalam bentuk yang disetujui oleh para pihak. Dokumentasi tersebut dapat menjadi bukti bahwa masyarakat adat telah memberikan persetujuannya, beserta syarat-syarat yang harus dipenuhi oleh pemrakarsa proyek. ${ }^{35}$

\section{G. Melakukan Verifikasi atas Persetujuan Masyarakat Adat}

Verifikasi dari pihak ketiga yang independen diperlukan mengingat proses FPIC sangat rentan untuk dimanipulasi. Misalnya, pihak investor dengan didukung oleh oknum dari pemerintah daerah melakukan pendekatan kepada orang-orang tertentu di dalam komunitas masyarakat adat, memberikan informasi yang menyesatkan dan memanipulasi luasan tanah dan hutan yang akan digunakan.

Pada umumnya, terdapat dua pendekatan dalam menentukan siapa yang akan menjadi verifikator independen FPIC. Pertama, verifikasi keabsahan hasil yang berbasis FPIC bisa dipercayakan kepada badan pemerintah yang akan dibebani tanggung jawab untuk menjamin bahwa prosedur yang sesuai dengan hukum telah diikuti dan persetujuan diberikan atau tidak diberikan setelah menempuh suatu proses yang semestinya. Hal ini lazim diterapkan oleh negara yang telah mewajibkan FPIC dalam hukum nasionalnya seperti Filipina. Kedua, mempercayakan tugas verifikasi ini kepada auditor independen dari luar. Dalam hal ini auditor mempelajari

\footnotetext{
34 Tim Penulis Pokja IV. Panduan Pelaksanaan... hal, 36.

35 World Wildlife Fund. Free, Prio... hal. 6.
} 
pendokumentasian dan melakukan wawancara dengan pihak-pihak yang terkait untuk menjajaki sampai sejauh mana perjanjian antara masyarakat dan perusahaan telah mematuhi prosedur yang disyaratkan. Hal ini lazim diterapkan apabila FPIC hadir sebagai standar sukarela/voluntary standard yang diterima oleh perusahaan swasta namun belum disyaratkan dalam undang-undang nasional. Dalam kedua pendekatan ini, apabila proses FPIC dianggap telah memenuhi standar, sebuah sertifikat akan diterbitkan yang kemudian dapat dipakai sebagai bukti bahwa persetujuan telah diberikan oleh masyarakat adat secara bebas dan adil. ${ }^{36}$

Beberapa faktor yang dapat menyebabkan proses FPIC tidak verified diantaranya:

- Pemrakarsa proyek bernegosiasi dengan perwakilan masyarakat adat/penghulu adat yang salah dan tidak diakui oleh masyarakat adat berdasarkan hukum adat yang berlaku;

- Pemrakarsa proyek bernegosiasi dengan cara yang tidak memperhatikan kepentingan masyarakat adat;

- Pemrakarsa proyek tidak memberitahukan dampak negatif dari proyek yang diusulkan;

- Pemrakarsa proyek tidak memberikan waktu yang cukup bagi masyarakat adat untuk mendiskusikan rencana proyek atau untuk mencari informasi dan saran dari pihak lain (second opinion) tentang proyek tersebut.

\section{H. Tahap Sosialisasi Hasil}

Setiap tahapan FPIC (proses dan pengambilan keputusan) perlu disosialisasikan kepada seluruh komponen masyarakat yang akan terkena dampak, termasuk para pemangku kepentingan di tingkat desa, kecamatan, kabupaten dan provinsi. ${ }^{37}$

36 Marchus Colchester dan Maurizio Farhan Ferrari. Menjadikan FPIC -Prinsip Persetujuan tanpa Paksaan atas Dasar Informasi Awal - Berjalan: Tantangan dan Peluang bagi Masyarakat Adat. (Forest People Programme: 2007). Hal 15.

${ }^{37}$ Tim Penulis Pokja IV. Panduan Pelaksanaan... hal, 36. 


\section{Monitoring dan Evaluasi (Monev)}

Monev dilakukan untuk memastikan tidak ada pelanggaran terhadap ketentuan-ketentuan yang telah disepakati dan harus bersifat partisipatif yaitu melibatkan semua pihak yang berkepentingan termasuk masyarakat adat. Monev ini juga harus didukung dengan pembentukan tim independen yang bertugas menangani komplain dari masyarakat. Beberapa hal penting dalam penanganan komplain tersebut diantaranya sesuai dengan prinsip: keterjangkauan oleh masyarakat, independensi, pengelolaan yang transparan, dan efektif dalam memberikan respon. ${ }^{38}$

\section{Mengapa FPIC dapat Menjadi \\ Instrumen Hukum Progresif untuk Melindungi \\ Hak-hak Masyarakat Adat dalam Kegiatan Usaha Migas?}

\subsection{Teori Hukum Strategis}

Hukum progresif merupakan sebuah gagasan yang mengalir, yang tidak mau terjebak dalam status quo, sehingga menjadi mandeg. Hukum progresif menempatkan manusia sebagai faktor penting dalam kajian dan penegakkan hukum. ${ }^{39}$ Konsep ini bermuara kepada asas besar bahwa 'hukum adalah untuk manusia', karena kehidupan manusia penuh dengan dinamika dan berubah dari waktu ke waktu. ${ }^{40}$ Hal tersebut dilukiskan oleh Satjipto Rahardjo dengan kalimat sebagai berikut:

"Hukum adalah institusi yang secara terus menerus membangun dan mengubah dirinya menuju kepada tingkat kesempurnaan yang lebih baik. Kualitas kesempurnaan di sini bisa diverifikasi ke dalam faktor-faktor keadilan, kesejahteraan, kepedulian kepada rakyat dan lain-lain. Inilah hakikat 'hukum yang selalu dalam proses menjadi' (law as a process, law in the making). Hukum tidak ada untuk hukum itu sendiri, tetapi untuk manusia." 41

38 Ibid.

39 Satjipto Rahardjo (a), Penegakan Hukum: Suatu Tinjauan Sosiologis, (Yogyakarta: Genta Publishing, 2009), hal. 1-2.

40 Satjipto Rahardjo (b), Hukum dalam Jagat Ketertiban, (Jakarta: UKIPers, 2006), hal. 151.

41 Satjipto Rahardjo (c), Hukum Progresif: Hukum yang Membebaskan, Jurnal Hukum Progresif (Vol.1/No.1/April 2005) 
Konsep mengenai hukum progresif ini lahir bukan tanpa sebab. Aliran tersebut muncul sebagai akibat dari ketidakpuasan pada aliran positivisme hukum yang selama ini dianut oleh para penegak hukum, para sarjana dan akademisi hukum di Indonesia. ${ }^{42}$

Menurut Satjipto Raharjo, hukum yang progresif adalah hukum yang mampu mengikuti serta menjawab perkembangan dan perubahan zaman. ${ }^{43}$ Hukum progresif bukanlah konsep yang berdiri sendiri karena eksplanasi persoalan hukum tidak bisa dilepaskan dari kebersinggungannya dengan konsep hukum lain seperti teori hukum responsif (responsive law) dari Nonet \& Selznick yang menghendaki agar hukum diposisikan sebagai fasilitator yang merespon kebutuhan dan aspirasi warga masyarakat. Dengan kata lain, hukum harus menawarkan lebih dari sekadar prosedural justice, berorientasi pada keadilan, memperhatikan kepentingan publik, dan lebih dari pada itu harus mengedepankan substansial justice. ${ }^{44}$

Hukum dalam perspektif hukum progresif bukanlah semata-mata rule of logic, tetapi social structure and behaviour. Hukum tanpa memperhatikan rasa keadilan masyarakat sama halnya mengingkari kepastian hukum itu sendiri. Bahwa penegakan hukum sangat terkait dengan masyarakat sehingga tidak asosial. Oleh sebab itu itu, ketika terjadi permasalahan di dalam hukum, maka hukumlah yang harus ditinjau dan diperbaiki, bukan manusia yang dipaksapaksa untuk dimasukkan ke dalam skema hukum. ${ }^{45}$

\subsection{FPIC sebagai Instrumen Hukum Strategis untuk Melindungi Hak- hak Masyarakat Adat dalam Kegiatan Usaha Migas}

Kebutuhan domestik atas minyak bumi yang semakin meningkat, memaksa SKK Migas untuk terus menggenjot laju produksi. Pada tahun 2014, target produksi minyak ditetapkan sebesar 1 juta barel per hari (bph). Untuk memenuhinya, pemerintah mematok target pengeboran di angka 1.456 sumur. ${ }^{46}$

42 Dey Ravena, Konsepsi dan Wacana Hukum Progresif, Jurnal Suloh (Vol. VII. No.1 April 2009), hal. 17.

43 Satjipto Rahardjo (d), Hukum dan Birokrasi, Makalah pada diskusi Panel Hukum dan Pembangunan dalam Rangka Catur Windu Fakultas Hukum UNDIP, 20 Desember 1998, hal. 5

${ }^{44}$ Dey Ravena, Ibid., hal. 20.

${ }^{45}$ Satjipto Rahardjo (c), Ibid., hal. 5.

${ }^{46}$ Diemas Kresna Duta. Realisasi Pengeboran Sumur Belum Capai Target. http:// www.cnnindonesia.com/ekonomi/20141110092958-85-10507/realisasi-pengeboransumur-belum-capai-target//, diakses pada 19 Desember 2014. 
Artinya, kedepan akan semakin banyak aktivitas pengadaan tanah untuk mendukung kegiatan usaha hulu migas ini.

Tidak hanya itu, di sektor hilir Pemerintah Jokowi-JK berkomitmen untuk melakukan konversi Bahan Bakar Minyak (BBM) ke Bahan Bakar Gas (BBG) dalam kurun waktu tiga tahun. Cara yang ditempuh adalah dengan memperbanyak infrastruktur seperti pipanisasi, pembangunan SPBG dan Terminal. ${ }^{47}$ Kegiatan ini juga akan membutuhkan pengadaan tanah dalam jumlah yang sangat besar, dari Sabang sampai Merauke.

Agenda pemerintahan baru di sektor migas yang sangat ambisius ini bukan tidak mungkin membutuhkan tanah ulayat. Dalam hal demikian, masyarakat adat harus dilibatkan dalam pembuatan kebijakan yang akan berdampak langsung terhadap kehidupannya. Hal ini sejalan dengan asas partisipatif ${ }^{48}$ dalam Undang-undang No. 32 Tahun 2009 tentang Perlindungan dan Pengelolaan Lingkungan Hidup yang berarti setiap anggota masyarakat didorong untuk berperan aktif dalam proses pengambilan keputusan dan pelaksanaan perlindungan dan pengelolaan lingkungan hidup, baik secara langsung maupun tidak langsung.

Pembangunan yang partisipatif merupakan wujud tata kelola pemerintahan yang baik (good governance). Akses partisipasi masyarakat dalam pengambilan keputusan, utamanya dalam pengelolaan lingkungan dan sumber daya alam, akan mendorong lahirnya produk kebijakan yang tidak hanya mementingkan pertumbuhan ekonomi tetapi juga menjaga kelestarian lingkungan dan hak-hak dasar masyarakat, melalui minimalisasi biaya sosial, ekonomi dan lingkungan hidup. ${ }^{49}$

Sebaliknya, pembangunan yang tidak partisipatif dan menerobos hakhak masyarakat adat merupakan pelanggaran terhadap hak asasi manusia. Berdasarkan doktrin tanggung jawab negara dalam hak asasi manusia, maka mekanisme FPIC meliputi penghormatan (to respect), perlindungan (to protect), pemenuhan (to fulfill) dan penegakan hak masyarakat adat atas sumber daya alamnya dalam setiap tindakan yang dilakukan pihak luar. ${ }^{50}$

${ }^{47}$ Feby Dwi Sutianto. Jokowi-JK Bakal Konversi BBM ke BBG dalam 3 Tahun. http:// finance.detik.com/read/2014/06/20/213145/2614884/1034/jokowi-jk-bakalkonversi-bbm-ke-bbg-dalam-3-tahun, diakses pada 19 Desember 2014.

${ }^{48}$ Pasal 2 huruf $(\mathrm{k})$, UUPPLH.

49 Indonesian Center for Environmental Law (ICEL), Membuka Ruang, Menjembatani Kesenjangan, (Jakarta:ICEL, 2006)

50 Yance Arizona, Mempertimbangkan FPIC..., diakses pada 19 Desember 2014. 
Prosedur FPIC, apabila dikaitkan dengan teori hukum strategis menurut Satjipto Raharjo, dapat dikategorikan sebagai instrumen hukum strategis karena pengaplikasiannya dapat bermanfaat:

a. menjamin ruang partisipasi masyarakat adat dalam setiap tahapan perencanaan, pengambilan keputusan, pelaksanaan, hingga evaluasi suatu kebijakan yang berdampak langsung pada kehidupannya;

b. mencegah konflik antar masyarakat adat dengan pihak lain;

c. Menjaga keberlanjutan lingkungan sebab penguatan masyarakat yang berada pada kawasan sumberdaya alam, yang selama ini bercorak komunal, dapat menghadang kerusakan lingkungan dari ketamakan individu dan korporasi; ${ }^{51}$ dan

d. mengentaskan kemiskinan (poverty alleviation). Untuk poin yang terakhir ini, hubungan antara FPIC dengan pengentasan kemiskinan sifatnya memang tidak langsung tetapi sangat dekat satu sama lain. Pembebasan tanah ulayat yang merupakan salah satu harta masyarakat adat paling berharga tanpa persetujuan kompensasi yang memadai akan menyeret masyarakat ke dalam lubang kemiskinan yang lebih dalam. ${ }^{52}$ Pembukaan Wilayah Kerja Migas membuat masyarakat berburu dan nomadik terbelit dalam sempitnya ruang mencari nafkah dan sulitnya menjamin pasokan makanan.

\section{Bagaimana FPIC dapat Meningkatkan Kepastian Hukum Bagi Investasi di Sektor Migas?}

Prosedur FPIC apabila diimplementasikan dengan itikad baik dan sungguh-sungguh dapat menghasilkan social license bagi perusahaan. Social license adalah sebuah istilah yang berkembang di dunia bisnis internasional untuk menunjukkan bahwa proyek yang dijalankan perusahaan disetujui, diterima dan bahkan didukung oleh masyarakat. Social License diberikan oleh masyarakat secara informal dan intangible/tidak berwujud. Sebagaimana diungkapkan oleh Pierre Lassonde, presiden Newmont Mining Corporation, "You don't get your social license by going to a government ministry and making an

51 Yance Arizona, Mempertimbangkan FPIC..., diakses pada 19 Desember 2014.

52 Bernadinus Steny, FPIC dalam..., hal. 9. 
application or simply paying a fee... It requires far more than money to truly become part of the communities in which you operate." 53

Karena sifatnya yang tidak berwujud, sulit untuk menentukan apakah social license telah diperoleh. Namun demikian social license termanifestasi dalam berbagai bentuk seperti tingkat kepercayaan masyarakat yang tinggi terhadap kredibilitas perusahaan serta tidak adanya oposisi yang secara aktif mengkampanyekan penolakan terhadap keberadaan perusahaan. Social license juga bersifat dinamis dan tidak permanen mengingat kepercayaan, opini dan persepsi masyarakat dapat berubah. Karena itu social license harus terus dijaga dan dipelihara. ${ }^{54}$

Dari perspektif pengusaha, social license sangatlah penting karena:

1. Pemrakarsa proyek dapat memperoleh legitimasi atas keberadaan dan aktivitasnya dari perspektif masyarakat lokal;

2. Meminimalisir risiko penundaan proyek;

3. Meyakinkan pemegang saham dan investor bahwa perusahaan telah mengelola risiko sosial dan risiko-risiko lainnya dengan baik serta tidak melanggar HAM;

4. Meyakinkan pemerintah dan pemangku kepentingan lainnya bahwa perusahaan benar-benar berusaha untuk menghasilkan performance yang baik;

5. Melindungi reputasi perusahaan.

Berikut ini adalah contoh pentingnya implementasi FPIC dalam dinamika hubungan antara perusahaan ekstraktif dengan masyarakat adat:

\section{Hamersley Iron Pty Limited di Australia}

Pada awal tahun 1990an, Hamersley Iron Pty Limited, anak perusahaan Rio Tinto, berencana mengembangkan tambang biji besi dan jalur kereta api di Yandicoogina di kawasan Pilbara, Australia. Beberapa kelompok penduduk asli (Aborigin) tinggal di kawasan dekat tambang yang akan dibuka tersebut. Hamersley menghabiskan waktu empat bulan untuk melakukan kegiatan pemetaan sosial. Berdasarkan pemetaan tersebut, perundingan dilakukan dengan perwakilan suku Aborigin dari

53 http://socialicense.com/definition.html, diakses pada 27 Oktober 2014. Terjemahan bebas: Anda tidak akan mendapatkan izin sosial dengan cara pergi ke kementerian, membuat permohonan atau dengan membayar fee... Dibutuhkan lebih dari uang untuk benar-benar menjadi bagian dari masyarakat di tempat perusahaan Anda beroperasi.

${ }^{54}$ Brian F. Yates dan Celesa L. Horvath, Social License to Operate: How to Get it. and How to Keep It. Working Paper. (Canada: Pacific Energy Summit, 2013), hal 3. 
Januari sampai Juni 1996 dan menghasilkan Perjanjian Penggunaan Lahan Yandicoogina yang memberikan dasar bagi kerangka kerjasama jangka panjang antara Hamersley dan pihak Aborigin. Dengan adanya kerja sama ini, Hamersley dapat mengurangi lamanya proses perijinan, menyelesaikan konstruksi dengan biaya 100 juta dolar AS lebih murah dari pada yang dianggarkan, dan memulai produksi enam bulan lebih cepat. ${ }^{55}$

\section{Newmont Mining Corporation di Peru}

Yanacocha adalah proyek pertambangan emas terbesar di Amerika Latin dan terbesar kedua di dunia. Nama Yanacocha berasal dari nama danau yang masih ada pada tahun 1992, namun setelah bertahun-tahun dilakukan open pit mining danau tersebut berubah jadi tandus dengan kawah yang sangat besar. Proyek ini akan dilanjutkan dengan nama Mina Conga dan akan menyebabkan lenyapnya empat danau lain yang merupakan sumber mata air dan mata pencaharian bagi masyarakat. Baik masyarakat adat maupun masyarakat lokal tidak menyetujui proyek pertambangan emas tersebut. Pada bulan November 2011, ratusan orang berdemonstrasi di Cajamarca dan menyebabkan pembangunan proyek terhenti. Sampai saat ini, terdapat 5 korban jiwa yang diakibatkan oleh respon kekerasan dari aparat keamanan terhadap demonstran. Newmont mengklaim bahwa ia merugi 2 juta dolar Amerika Serikat setiap harinya sejak demonstrasi melumpuhkan operasinya. ${ }^{56}$

Pentingnya penerapan FPIC ini juga ditegaskan oleh putusan InterAmerican Human Right System atas kasus Samaraka People v. Suriname. Dalam putusan ini, pemerintah Suriname dinyatakan bersalah atas tindakannya memberi konsesi sumber daya alam kepada perusahaan swasta tanpa meminta persetujuan dari masyarakat adat Samaraka. Majelis hakim menyatakan bahwa sebelum proyek pembangunan dilangsungkan, pemerintah seharusnya melakukan proses konsultasi dengan itikad baik, menggunakan sarana yang menurut adat dapat diterima dan bertujuan untuk mencapai kesepakatan dari Samaraka People. ${ }^{57}$

Putusan lain yang dapat menjadi preseden dalam pengakuan hak masyarakat adat di dunia internasional adalah kasus Kichwa People of Sarayaku $v$. Ecuador. Kasus ini bermula dari diterbitkannya izin eksplorasi dan eksploitasi minyak oleh Pemerintah Ekuador kepada perusahaan swasta dalam lingkup

55 Patrick Anderson. Free, Prior...Hal. 36.

${ }^{56}$ Marianne Coss and Emily Greenspan. Oil, Gas... hal. 16.

57 Tara Ward. The Right to FPIC: Indigenous Peoples' Participation Rights within International Law. Northwestern Journal of International Human Rights Volume 10, Issue 2, 2011. hal. 63 . 
wilayah yang ditempati secara adat oleh Kichwa People. Majelis hakim kemudian menyatakan Pemerintah Ekuador bersalah karena telah melanggar hak kepemilikan (right to property) dan hak untuk berpartisipasi dalam pemerintahan karena tidak menyelenggarakan konsultasi yang efektif dengan masyarakat terdampak sebelum diterbitkannya izin tersebut. ${ }^{58}$

Dari contoh di atas, kita dapat melihat bahwa dengan menerapkan FPIC, manfaat bagi perusahaan sangatlah besar baik secara materil maupun immateriil seperti nama baik, reputasi, social license dan kepastian hukum. Sebaliknya, tanpa FPIC perusahaan akan mengalami risiko demonstrasi, pencitraan negatif, pencabutan izin, penghentian paksa dan gugatan hukum. Resiko-resiko ini tentunya akan menghambat kegiatan eksplorasi, pelaksanaan komitmen pengeboran dan pembangunan infrastruktur migas. Karena itu pemerintah harus segera menormakan FPIC dalam kerangka hukum nasional dan menciptakan instrumen-instrumen pendukungnya untuk meningkatkan kepastian hukum bagi investasi di sektor migas.

\section{Bagaimana Strategi untuk Menerapkan FPIC dalam Kebijakan Pengadaan Tanah untuk Kegiatan Usaha Migas di Indonesia?}

Penulis memetakan setidaknya terdapat empat strategi untuk mendorong penerapan FPIC di Indonesia khususnya di sektor migas, yaitu 1) Merevisi UU No. 22 Tahun 2001 tentang Minyak dan Gas Bumi (UU Migas); 2) Merevisi UU No. 2 Tahun 2012 tentang Pengadaan Tanah bagi Pembangunan Untuk Kepentingan Umum (UU Tentang Pengadaan Tanah bagi Kepentingan Umum); 3) Menormakan FPIC dalam RUU tentang Pengakuan dan Perlindungan Hak Masyarakat Hukum Adat;atau 4) Mencantumkan persyaratan FPIC dalam pinjaman bank.

\subsection{Memasukkan Ketentuan tentang FPIC dalam Revisi UU Migas}

Di dalam rancangan revisi UU Migas, perlu diatur ketentuan tentang kewajiban pengusaha baik Badan Usaha maupun Badan usaha Tetap untuk meminta persetujuan masyarakat adat sebelum melakukan kegiatan usaha migas yang mempunyai dampak pada tanah, wilayah, sumber daya alam, budaya dan sistem pemerintahan adat. Berikut ini usulan pasal yang sesuai dengan standar hukum internasional tentang perlindungan hak-hak masyarakat adat:

58 Tara Ward. The Right..., hal. 64. 
(1) Dalam hal tanah yang akan digunakan untuk kegiatan usaha minyak dan gas bumi merupakan tanah masyarakat adat, perolehan tanah dilakukan melalui:

a. persetujuan dari masyarakat adat yang bersangkutan;

b. pemberian informasi yang lengkap dan akurat dengan bahasa yang mudah dimengerti tentang Kegiatan Usaha Migas yang akan berdampak pada tanah, wilayah, sumber daya alam, budaya dan sistem pemerintahan adat;

c. pemberian restitusi dan kompensasi yang layak dan adil atas wilayah adat baik daratan maupun perairan, dan sumber daya alam yang dimiliki secara turun temurun yang diambil alih, dikuasai dan digunakan untuk Kegiatan Usaha Migas;

d. pemberian hak untuk kembali ke wilayah adat ketika Kegiatan Usaha Migas telah selesai.

(2) Pemberian restitusi dan kompensasi sebagaimana dimaksud pada ayat (7) diberikan dalam bentuk:

a. Uang;

b. Tanah pengganti;

c. Pemukiman kembali;

d. Kepemilikan saham; dan/atau

e. Bentuk lain yang disepakati oleh kedua belah pihak

(3) Mekanisme lebih lanjut tentang prosedur penggunaan tanah masyarakat adat untuk kegiatan usaha minyak dan gas bumi akan diatur oleh Peraturan Pemerintah.

\subsection{Merevisi Undang-Undang tentang Pengadaan Tanah bagi Pembangunan Untuk Kepentingan Umum}

Undang-Undang No. 2 Tahun 2012 tentang Pengadaan Tanah Bagi Pembangunan untuk Kepentingan Umum (UU Pengadaan Tanah) mengatur tentang prosedur pengadaaan tanah untuk Kepentingan Umum dimana infrastruktur minyak dan gas ${ }^{59}$ dikategorikan sebagai Kepentingan Umum ${ }^{60}$

${ }^{59}$ Yang dimaksud Infrastruktur minyak dan gas bumi adalah infrastruktur yang terkait dengan kegiatan usaha hulu minyak dan gas bumi yang mencakup kegiatan eksplorasi, eksploitasi, transmisi, dan/atau distribusi (Penjelasan Pasal 7 ayat (2)). 
berdasarkan Pasal 10. Sebenarnya UU ini sudah cukup maju dengan mensyaratkan adanya konsultasi publik dengan melibatkan Pihak yang Berhak $^{61}$ (termasuk di dalamnya masyarakat adat) dan masyarakat yang terkena dampak dengan tujuan untuk mendapatkan kesepakatan lokasi rencana pembangunan. Konsultasi Publik dalam UU ini didefinisikan sebagai proses komunikasi dialogis atau musyawarah antarpihak yang berkepentingan guna mencapai kesepahaman dan kesepakatan dalam perencanaan pengadaan tanah bagi pembangunan untuk kepentingan umum. ${ }^{62}$ Namun sayangnya meskipun melalui mekanisme Konsultasi Publik, masyarakat adat tetap tidak dapat mempertahankan haknya untuk menyatakan setuju atau tidak setuju pada kegiatan usaha yang akan berdampak pada pada tanah, wilayah dan mata pencaharian masyarakat adat. Hal ini dikarenakan:

I. Apabila terdapat pihak yang keberatan mengenai rencana lokasi pembangunan, dibentuk tim yang bertugas menginventarisasi masalah yang menjadi alasan keberatan, melakukan pertemuan atau klarifikasi dengan pihak yang keberatan dan membuat rekomendasi diterima atau ditolaknya keberatan kepada Gubernur (Pasal 21 ayat (3) UU Pengadaan Tanah);

II. Gubernur berdasarkan rekomendasi tersebut mengeluarkan surat diterima atau ditolaknya keberatan atas rencana lokasi pembangunan. (Pasal 21 ayat (6) UU No.2 Tahun 2012).

Pada akhirnya, gubernur dapat menolak keberatan yang diajukan oleh masyarakat adat berdasarkan rekomendasi tim yang melakukan kajian atas keberatan rencana lokasi pembangunan. Tim ini beranggotakan 5 orang dari unsur pemerintahan dan 1 orang akademisi63, suatu komposisi yang dapat

${ }^{60}$ Kepentingan Umum adalah kepentingan bangsa, negara, dan masyarakat yang harus diwujudkan oleh pemerintah dan digunakan sebesar-besarnya untuk kemakmuran rakyat. (Pasal 1 angka 6 UU No.2 Tahun 2012).

${ }^{61}$ Yang dimaksud dengan Pihak yang Berhak adalah pihak yang menguasai atau memiliki objek pengadaan tanah (Pasal 1 angka 3 UU No. 2 Tahun 2012). Selanjutnya, Penjelasan Pasal 40 UU No. 2 Tahun 2012 menyatakan bahwa Pihak yang Berhak atas Ganti Rugi antara lain: a. Pemegang hak atas tanah; b. Pemegang hak pengelolaan; c. nasdzir, untuk tanah wakaf; d. Pemilik tanah bekas milik adat; e. Masyarakat hukum adat; f. Pihak yang menguasai tanah negara dengan itikad baik; g. Pemegang dasar penguasaan atas tanah; dan/atau; h. Pemilik bangunan, tanaman atau benda lain yang berkaitan dengan tanah.

${ }_{62}$ Pasal 1 angka 8 UU No.2 Tahun 2012.

63Tim yang akan melakukan kajian atas keberatan rencana lokasi pembangunan terdiri atas: a. Sekretaris daerah provinsi; b. Kepala kantor wilayah BPN sebagai sekretaris merangkap anggota; c. Instansi yang menangani urusan di bidang perencanaan pembangunan daerah; d. Kepala kantor wilayah kementerian hukum dan HAM; e. Bupati/walikota; Akademisi (Pasal 21 ayat (3) UU No.2 Tahun 2012) 
dikatakan ekslusif karena tidak terdapat perwakilan dari Organisasi Masyarakat Sipil (OMS) yang bergerak di bidang advokasi hak-hak masyarakat adat sehingga rekomendasi yang dihasilkan akan cenderung tidak mencerminkan aspirasi sebenarnya dari masyarakat adat. Lebih jauh, kewenangan gubernur untuk menolak keberatan yang diajukan oleh masyarakat adat yang diberikan oleh UU ini telah menegasikan prinsip-prinsip FPIC sebagaimana diatur di dalam UN Declaration on Indigenous People, sehingga klausul tersebut perlu direvisi.

\subsection{Menormakan FPIC dalam RUU Pengakuan dan Perlindungan Hak Masyarakat Hukum Adat dan Mendorong agar RUU tersebut Masuk dalam Prolegnas 2015}

UU Pengakuan dan Perlindungan Hak Masyarakat Adat (UU PPHMA) merupakan mandat undang-undang Dasar 1945 Pasal 18B ayat (2) UUD 1945. Sayangnya meskipun sejak setahun yang lalu sidang paripurna DPR telah resmi menjadikan UU PPHMA sebagai salah satu RUU inisiatif DPR-RI, hingga hari ini RUU tersebut belum disahkan. Padahal UU PPHMA sangat krusial karena akan memberikan kejelasan tentang hak masyarakat adat atas tanah ulayat dan sumber daya alam, baik yang berada di permukaan tanah maupun di dalam tanah. Selain itu, RUU PPHMA merupakan payung hukum yang tepat untuk menormakan FPIC karena UU ini fokus mengatur tentang masyarakat adat. Sehubungan dengan tidak adanya jaminan bahwa pembahasan RUU ini akan dilanjutkan DPR di tahun depan, sangatlah penting untuk mendorong agar RUU ini masuk dalam agenda Prolegnas 2015.

Dari segi substansi, RUU PPHMA sebaiknya memiliki bab/bagian tersendiri tentang FPIC meliputi prosedur, prinsip dan pembentukan/penunjukan tim independen yang akan menjalankan fungsi verifikasi sebagaimana telah penulis uraikan pada bab dua. RUU PPHMA juga harus dengan tegas mewajibkan FPIC untuk semua aktivitas yang akan dilangsungkan di ruang kehidupan masyarakat adat maupun yang akan berdampak kepada tanah, kawasan, sumber daya dan perikehidupan mereka. Agar memastikan pengaturan ini dapat berjalan efektif, RUU PPHMA perlu mengatur:

a. Sanksi yang dapat dibebankan kepada perusahaan dalam hal tidak menjalankan prosedur FPIC;64

64 misalnya berupa pembekuan atau pencabutan izin pengelolaan sumber daya alam. 


\begin{abstract}
b. Mekanisme penyelesaian sengketa antar masyarakat adat maupun antara masyarakat adat dengan pihak lain; dan

c. Pemberdayaan masyarakat adat.
\end{abstract}

\title{
6.4 Mendorong adanya Peraturan Bank Indonesia yang Mensyaratkan Klausul Perlindungan terhadap Hak-hak Masyarakat Adat dalam Perjanjian Kredit
}

Industri migas merupakan industri padat modal yang membutuhkan kredit dari perbankan untuk mendukungnya. Dalam hal ini sektor perbankan dapat digerakkan untuk berperan serta dalam memastikan bahwa kredit tersebut tidak dipergunakan untuk kegiatan yang merampas hak-hak masyarakat adat. Caranya adalah dengan mencantumkan klausul perlindungan terhadap hak-hak masyarakat adat dalam perjanjian kredit. Hal ini selain sesuai dengan UN Declaration for Indigenous People, juga sejalan dengan prinsip kehati-hatian yang wajib dipegang teguh sektor perbankan dalam memberikan pembiayaan. Prinsip kehati-hatian (prudential principle) berdasarkan UU No. 7 Tahun 1992 tentang Perbankan sebagaimana telah diubah oleh UU No. 10 Tahun 1998 adalah suatu prinsip yang menegaskan bahwa bank dalam menjalankan kegiatan usaha baik dalam penghimpunan terutama dalam penyaluran dana kepada masyarakat harus sangat berhati-hati. Tujuan dilakukannya prinsip kehati-hatian ini agar bank selalu dalam keadaan sehat menjalankan usahanya dengan baik dan mematuhi ketentuan-ketentuan dan norma-norma hukum yang berlaku di dunia perbankan.

Pada tahun 2013 lalu, Bank Mandiri memimpin penyaluran kredit sindikasi sebesar AS\$260 juta kepada anak perusahaan PT Medco E\&P Tomori Sulawesi untuk pengembangan dan konstruksi lapangan hulu gas Senoro (Blok Senoro-Toili). ${ }^{65}$ Bayangkan apabila proyek ini tidak dapat berjalan dengan baik atau bahkan berhenti di tengah jalan karena adanya konflik dengan masyarakat adat. Tentu hal ini berpotensi menyebabkan return capacity dari kredit yang diberikan tidak dapat dijamin kolektabilitasnya (kredit macet). Dengan jumlah kredit sebesar itu, cash flow bank akan terguncang yang pada akhirnya akan menurunkan tingkat kesehatan bank tersebut. Bagi bank yang dikelola dengan baik, tentu tidak akan mau menempuh risiko-risiko ini.

Lembaga Keuangan internasional seperti World Bank, International Finance Corporation (IFC) dan berbagai development banks di tingkat regional

65 Bank Mandiri, Mandiri Kucurkan Kredit Sindikasi \$260 Juta untuk Lapangan Gas

Medco Energi http://www.bankmandiri.co.id/corporate01/newsdetail.asp?id=NHBK28186912, diakses pada 19 Oktober 2014. 
seperti The Europian Bank for Reconstruction and Development, The Asia Development Bank dan The Inter-American Development Bank telah mengadopsi kebijakan perlindungan hak-hak masyarakat adat yang wajib diikuti oleh perusahaan untuk mendapatkan pembiayaan. IFC Performance Standard 7 on Indigenous People (PS7) adalah ketentuan yang paling sering dirujuk oleh perusahaan dan lembaga keuangan lainnyaserta direkomendasikan oleh The Equator Principle yang merupakan benchmark industri keuangan untuk risiko lingkungan dan risiko sosial.66 PS7 mengatur peran sektor swasta dalam meminimalisir dampak proyek terhadap masyarakat adat. PS7 bertujuan untuk:

- Memastikan bahwa proses pembangunan menjunjung tinggi hak asasi manusia, harkat dan martabat, aspirasi serta mata pencaharian masyarakat adat;

- Mengantisipasi dan menghindari dampak negatif proyek terhadap komunitas masyarakat adat, atau apabila tidak mungkin dihindari, perusahaan wajib meminimalisir dan/atau memberikan kompensasi atas dampak tersebut;

- Membangun dan memelihara hubungan yang berkelanjutan dengan masyarakat adat terdampak

- Memastikan bahwa hak masyarakat adat atas FPIC ditegakkan;

- Menghargai dan melestarikan budaya, kearifan lokal serta praktekpraktek yang selama ini dilakukan masyarakat adat. ${ }^{67}$

Sudah saatnya perbankan di Indonesia mencantumkan perlindungan terhadap hak-hak masyarakat adat dalam perjanjian kreditnya sebagaimana telah diterapkan oleh IFC dan lembaga keuangan internasional lain. Salah satu caranya adalah dengan mendorong adanya Peraturan Bank Indonesia yang memandatkan hal ini.

66 Anonim. About the Equator Principle http://www.equatorprinciples.com/index.php/about-ep/about-ep, diakses pada 19 Oktober 2014. Saat ini The Equator Principle telah diadopsi oleh 80 lembaga keuangan dari 34 negara yang membiayai lebih dari 75\% proyek pembangunan di seluruh dunia.

67 The Global Oil and Gas Industry Association for Environmental and Social Issues (IPIECA), Indigenous Peoples...hal. 8. 


\section{Kesimpulan}

Berdasarkan uraian yang telah Penulis kemukakan, maka dapat ditarik kesimpulan sebagai berikut:

1. FPIC merupakan instrumen hukum strategis yang dapat menjadi jawaban atas permasalahan masyarakat adat akibat pengelolaan sumber daya alam yang tidak partisipatif dan melanggar hak-hak masyarakat adat;

2. FPIC dapat meningkatkan kepastian hukum bagi investasi di sektor migas karena dapat menciptakan social license bagi perusahaan dalam menjalankan operasinya dan mengurangi resiko konflik sosial;

3. Untuk menerapkan FPIC dalam kebijakan pengadaan tanah untuk kegiatan migas di Indonesia, tulisan ini menawarkan empat strategi perubahan:

a. Memasukkan ketentuan tentang FPIC dalam revisi UU Migas;

b. Merevisi UU No. 2 Tahun 2012 tentang Pengadaan Tanah Bagi Pembangunan untuk Kepentingan Umum;

c. Menormakan FPIC dalam RUU PPHMA dan mendorong agar RUU tersebut masuk dalam Prolegnas 2015;

d. Mendorong adanya Peraturan Bank Indonesia yang Mensyaratkan Klausul Perlindungan terhadap Hak-hak Masyarakat Adat dalam Perjanjian Kredit. 


\section{Daftar Pustaka}

Aliansi Masyarakat Adat Nusantara. Jaringan akan Buat Peta Global Masyarakat Adat. $\quad$ http://www.aman.or.id/2013/10/03/jaringan-akan-buat-petaglobal-masyarakat adat/\#.VAuzhxYWS_w

Berita Satu. Komnas HAM: Hanya dari Kasus Tanah, Banyak HAM yang HAM yang Bisa Dilanggar. http://www.beritasatu.com/hukum/163078-komnashanya-dari-kasus-tanah-banyak-ham-yang-bisa-dilanggar.html

Berita Satu. Komnas hanya dari Kasus Tanah Banyak HAM yang Dilanggar. Sumber: http://www.beritasatu.com/hukum/163078-komnas-hanya-darikasus-tanah-banyak-ham-yang-bisa-dilanggar.html

Brian F. Yates dan Celesa L. Horvath. 2013. Social License to Operate: How to Get it, and How to Keep It. Working Paper. Canada: Pacific Energy Summit.

Bank Mandiri. Mandiri Kucurkan Kredit Sindikasi US\$260 Juta untuk Lapangan Gas Medco Energi. http://www.bankmandiri.co.id/corporate01/newsdetail.asp?id=NHBK28186912

Cielo Magno. 2013. FPIC in the Philippines: Regulations and Realities. Boston: Oxfam America.

Dewan Kehutanan Nasional dan UN-REDD Programme Indonesia. 2011. Rekomendasi Kebijakan: Instrumen Free, Prior, Informed Concent (FPIC) Bagi Masyarakat Adat dan atau Masyarakat Lokal yang Akan Terkena Dampak dalam Aktivitas Redd+ di Indonesia. Palu: DKN.

Dey Ravena. 2009. Konsepsi dan Wacana Hukum Progresif. Jurnal Suloh Vol. VII. No.1 April 2009.

Ekuatorial. Masyarakat Adat Lengkapi One Map Indonesia. http:/ / ekuatorial.com/climate-change/masyarakat-adat-lengkapi-onemap-indonesia

Equator Principles. About The Equator Principles. http://www.equatorprinciples.com/index.php/about-ep/about-ep. Saat ini The Equator Principle telah diadopsi oleh 80 lembaga keuangan dari 34 negara yang membiayai lebih dari 75\% proyek pembangunan di seluruh dunia.

First People Worldwide. 2013. Indigenous Rights Risk Report for the Extractive Industry. US: First People Worldwide. 
Hukumpedia. Mengapa Undang-undang Masyarakat Adat dibutuhkan. http://www.hukumpedia.com/masyarakat-adat/mengapa-undangundang-masyarakat-adat-dibutuhkan-hk522d348cacad7.html

Indonesian Center for Environmental Law (ICEL). 2006. Membuka Ruang, Menjembatani Kesenjangan, Jakarta: ICEL.

Investasi Indonesia. Indonesia SOS Energi Investasi Asing. http://indonesiainvest-today. /2013/11/indonesia-sos-energi$\underline{\text { investasi-asing-di.html }}$

Christina Hill et.al. 2010. Pedoman Untuk Persetujuan Bebas dan Sadar. Australia: Oxfam

Prabin Shakya dan Allan T Nash. 2013. Rights in Action: FPIC for Indigenous Peoples. Asia Indigenous Peoples Pact (AIPP).

SocialLicense.com. What is the Social License. http://socialicense.com/definition.html

Satjipto Rahardjo. 1988. Hukum dan Birokrasi. Makalah pada diskusi Panel Hukum dan Pembangunan dalam Rangka Catur Windu Fakultas Hukum UNDIP.

Satjipto Rahardjo (c), “Hukum Progresif: Hukum yang Membebaskan”, Jurnal Hukum Progresif (Vol.1/No.1/ April 2005)

The Global Oil and Gas Industry Association for Environmental and Social Issues (IPIECA). 2012. Indigenous Peoples and the Oil and Gas Industry. UK: IPIECA

Tim Penulis Pokja IV. 2011. Panduan Pelaksanaan FPIC dalam Program UN-REDD di Sulawesi Tengah. Palu: FAO, UNDP, UNEP.

United Nations. 2012. Report of the Working Group on the Universal Periodic Review: Indonesia. Human Rights Council.

United Nation. 2009. The State of the World's Indigenous Peoples. New York: UN.

Marcus Colchester. 2009. Prinsip FPIC: Sebuah Panduan bagi Para Aktivis. UK: Forest Peoples Programme.

Marianne Coss and Emily Greenspan. 2012. Oil, Gas and Mining Company Public Position on FPIC. US: Oxfam America.

Patrick Anderson. 2011. Free, Prior, and Informed Consent: Principles and Approaches for Policy and Project Development. Bangkok: GIZ \& RECOFTC. 
Robert Goodland. 2004. FPIC and the World Bank Group. Sustainable Development Law and Policy, Summer.

Tara Ward. 2011. The Right to Free, Prior, and Informed Consent: Indigenous Peoples' Participation Rights within International Law. Northwestern Journal of International Human Rights. US: Northwestern University.

World Wildlife Fund. 2011.Free, Prior, Informed Consent and Redd+: Guidelines and Resources. Switzerland: WWF.

Yance Arizona. 2010. Kertas Kerja Epistema: Satu Dekade Legislasi Masyarakat Adat: Trend Legislasi Nasional tentang Keberadaan dan Hak-hak Masyarakat Adat atas Sumber Daya Alam di Indonesia (1999-2009). Jakarta: Epistema. 